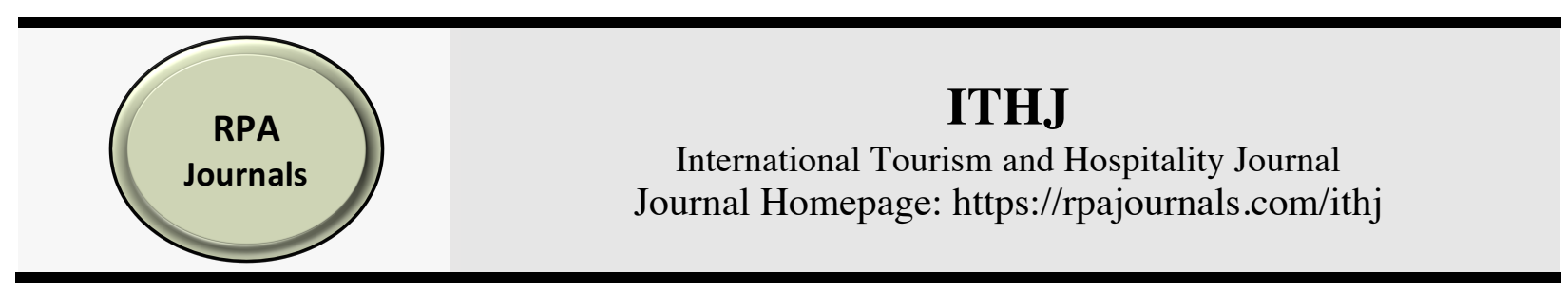

\title{
The Influence of Tourism Product and Tourism Expenditure on Tourist Preference through the Integration of Tourism Objects in Padang City
}

\author{
Hasdi Aimon ${ }^{1}$ \\ Hari Setia Putra ${ }^{2}$ \\ Nanda Alfarina*3 \\ Universitas Negeri Padang, Padang, Indonesia ${ }^{1,2,3}$
}

\begin{abstract}
This study aims to explain the influence of variables of tourism products and tourism expenditure on tourist preference in Padang City with tourism object integration as the mediating variable. The study, also explains the causal relationship between tourist preference and the integration of tourism objects in Padang City. The data was collected using a survey of visitors to tourist attractions in Padang City namely Pantai Padang, Pantai Air Manis, and Mount Padang using accidental sampling. The data was then analyzed using the moderated regression analysis. The study on tourism in Padang found an average tourist preference of 66.20 percent in a range of $48.01-84.39$ percent. Tourism product and tourism expenditure have a significant effect on tourist preference mediated by the variable of tourism object integration. The study also found a causal relationship between the integration of tourism objects and tourist preference. The study recommends that the Padang City Tourism Development Authority and the Padang City Government should intensify the integration of the tourism objects of Pantai Padang, Pantai Air Manis, and Mount Padang through increased infrastructure investments The use of information technology is key in developing tourism objects because it can be used as an effective promotional media, especially social media. However, the Padang City Government must first increase investment in the tourism sector to support tourism activities, especially transportation, recreational facilities, and infrastructure.
\end{abstract}

Keywords: Tourist Preference, Tourism Objects Integration, Tourism Product, Tourism Expenditure

*Corresponding author: Nanda Alfarina ${ }^{1}$; E-mail: nanda.lfarina@gmail.com

DOI: https://doi.org/10.37227/ITHJ-2020-02-32

\section{Introduction}

The tourism and travel sector is a key economic driver in countries around the world (Kuralbayev, Sevim, \& Abishev, 2017; Lorde, Li, \& Airey, 2015; Pham \& Vogt, 2019). As such, stimulating the tourism sector can be an effective strategy for economic development in developing as well as developed countries (Shafieea, Ghatari, Ali Rajabzadeh Hasanzadeha, \& Jahanyan, 2019; Shalini \& 
Masood, 2010; WTTC, 2019). The potential of the tourism sector is reflected by its contribution to GDP. In 2015 the direct contribution of the tourism sector to Indonesia's GDP was 5.47 percent. In 2016, this share increased to 5.82 percent. Meanwhile, the contribution of the tourism sector to the GRDP of Padang City in the same year amounted to 16.72 percent. Thus, the tourism sector contributes a larger share of the GRDP of Padang City than on the national level. Effective tourism development strategies are efficient tools in increasing the use of a region's natural resources to improve the regional economy.

The tourism industry offers several economic benefits, namely the creation of employment opportunities for local communities and the improvement of the quality of life and standards of living, while reducing poverty through the creation of integrated tourism (Andereck, Valentine, Knopf, \& Vogt, 2005; Hearne \& A, 2016; UNWTO, 2008). In 2018, the global number of tourist visits increased by 6 percent to 1.4 billion and is predicted to further increase to 1.8 billion by 2030 (UNWTO, 2019). The increased number of tourists is an opportunity for developing countries to promote their culture and tourism products. Revitalizing underdeveloped tourist destinations will impact on the number of future visits. Governments worldwide have invested in the tourism sector by redeveloping their tourist destinations to attract tourists, including the government of Padang City.

The Padang City Government has sought to increase economic activity in the tourism sector by developing integrated tourism destinations (Kawasan Wisata Terpadu - KWT). Padang aims to develop coastal tourism to utilize water tourism on the mainland. In addition, the development of Padang coastal tourism is also directed to exploit the potential of culinary tourism and cultural heritage tourism. Padang Beach is one of the three KWT destinations of Padang City. On average, tourist visits to Padang Beach have increased by 10.5 percent over the 2011-2016 period (DPMPTSP, 2017).

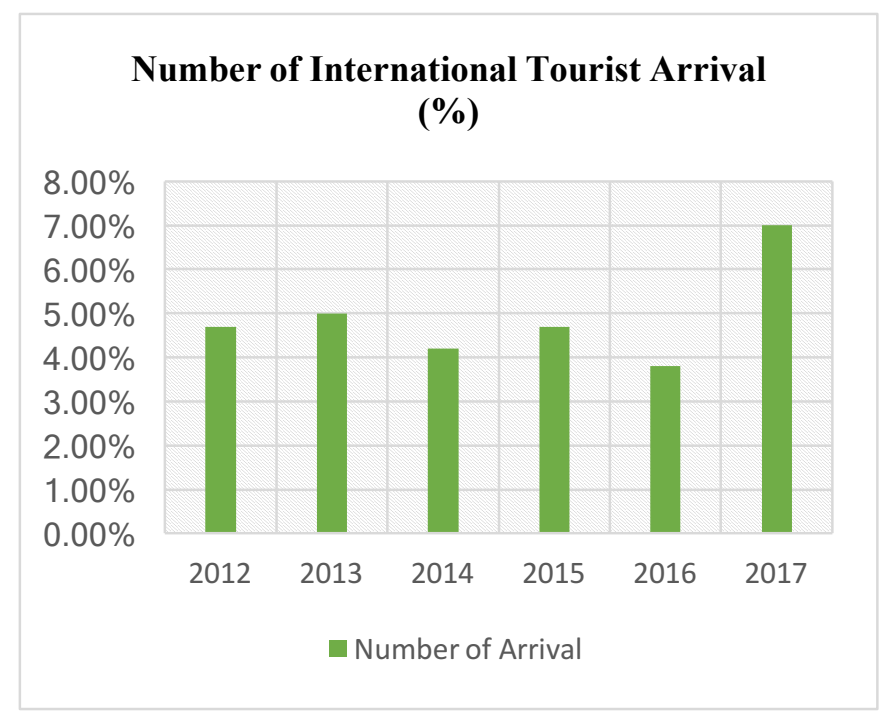

Figure 1. Number of International Tourist Arrival to Padang Beach Source: Statistic Indonesia 


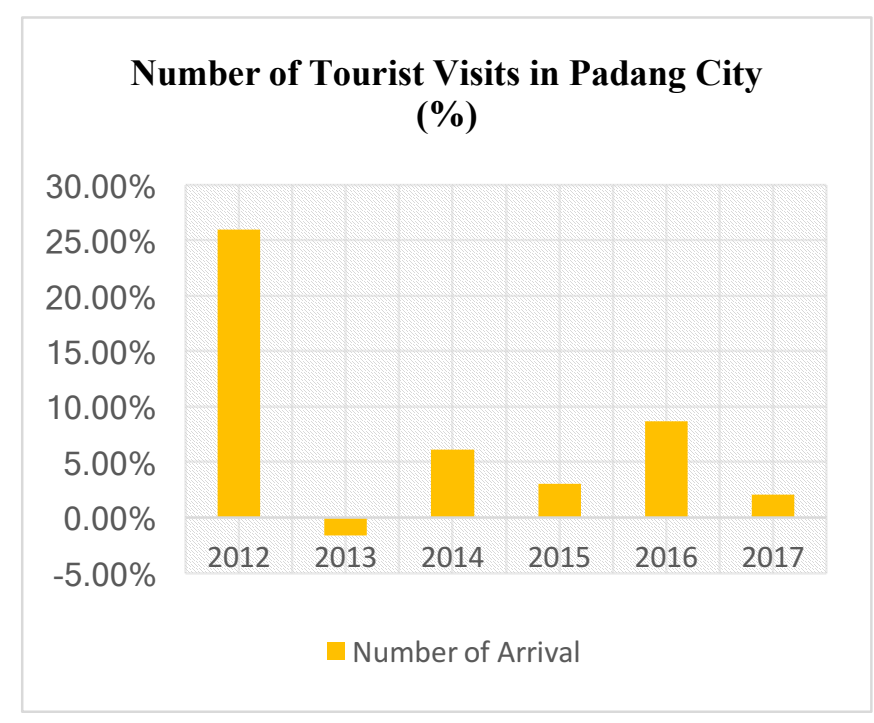

Figure 2. Number of Tourist Arrivals in Padang City Source: Statistics Indonesia

Figure 1 shows that the number of international tourist visits to Padang Beach has increased sharply in 2017. This increase indicates that Padang Beach is a key potential tourist attraction. Further developing this potential could attract more tourists as, currently, the tourismpotential of Padang Beach is not fully utilized. Successful tourism strategies can cultivate the relationship between cycles of growth in the tourism industry and economic growth. Notably, empirical analysis of the relationship between tourism growth and economic growth inOrganization for Economic Cooperation and Development (OECD) countries and in non-OECD countries found that tourism development has a greater impact on GDP in non-OECD countries compared to OECD countries (Lee \& Chang, 2008).

Generally, visitors are interested in visiting tourism destinations again. To realize this, it is important to ensure that tourists are satisfied with the experience of their visit. However, satisfaction (preference) alone may not be enough to make tourists revisit a destination. Therefore, more in-depth research is needed to study the various variables that affect tourist preference and tourist decisions to travel to Padang City. Decisions regarding tourist destinations need to be made based on an economic approach that specifically focuses on tourist preference and utility. (Zemla, 2016) divide tourism studies into two approaches, i.e., demand-side or supply-side approaches. The demand side approach is very important in analyzing tourist behavior, tourist satisfaction, and tourist preference. However, it limitation is subjectivity related to the different experiences and backgrounds of tourists. As such, this approach requires a more in-depth analysis. Further study is required of the travel experiences that are remembered by tourists to better understand tourist behavior. In this case, we must study cultural contact and the influence of visitor involvement on a memorable tourism experience.

\section{Literature Review}

The concept of integrated tourism has been debated in theory and practice (Oliver \& Jenkins, 2003). This concept can be defined as an inter-institutional integration that involves actors including partners who are indirectly involved in tourism. Whereas, other definitions explain tourism object integration as economic integration, namely the integration of economic sectors, especially retail and local industries. In simple terms, integrated tourism can be explained as tourism that connects economic, social, cultural, and natural structures with communities and tourist attractions. 
Specifically, tourism is connected between local resources, products, and communities (Toth \& David, 2010).

There has been a great shift in tourist preference due to the industrial revolution 4.0, i.e., technological advances and the increasing role of social media. In line with this, (Yilmaz \& Aytekin, 2018) have examined how past experiences affect tourists' decisions in choosing tourism products. Their study focused on accommodation, which is one of the key aspects of tourist destinations. One of the advances in information technology is the ease for tourists to look up other people's experiences before deciding on the right accommodation. This study emphasized the consideration of online ratings by visitors to accommodations. It indicated that these ratings do not affect the rating that the next visitor will give but they are a very important factor for people in deciding whether to use the tourism product facilities.

The main factors that determine tourist preferences are tourists' income, the cost of goods, and the cost of tourism services relative to the cost of alternative goods and services (Sevim, 2017). These costs include transportation costs, accommodation costs at tourist attractions, exchange rates that need to be taken into account when traveling abroad, as well as the population at the tourist destination (Shalini \& Masood, 2010). In addition, research by Lorde, Li \& Airey (Lorde et al., 2015) using the Augmented Gravity approach emphasized the importance of the word-of-mouth effect which is effective in building expectations and preferences of tourists through the development of social media.

Developing integrated tourism objects, it is necessary to develop a sustainable travel chain and add recreational transportation around the tourist attraction. In this case, developing public transportation can be very effective (Schiefelbusch, Jain, Schafer, \& Muller, 2007). However, a study conducted by (Toth \& David, 2010) showed conflicting results. This study found no significant relationship between increased accessibility (e.g., transportation) and income in the tourism sector.

(Cawley \& Gillmor, 2008) focused more on stakeholders in integrated rural touris and the need for promotion in the development of tourism areas as well as the coordination between various stakeholders and human resources. This study found that an integrated approach can address deficiencies and be a useful tool in facilitating sustainable tourism which can contribute to rural development.

\section{Research Methodology}

This research studied the tourist attractions in the Integrated Tourism Area of Padang City (Padang Beach, Air Manis Beach, and Mount Padang) with the visiting tourists as the research subjects. The data was collected through an on-site visitor survey questionnaires and interviews. This study focuses on Tourism Expenditure (X1), Tourism Product (X2), Tourism Object Integration (Y1) and Tourist Preference (Y2).

The research sampling method used was accidental sampling and it was analyzed with a moderated regression analysis. This study aimed to examine whether tourism expenditure (X1) and tourism products (X2) affect tourist preference (Y2) with tourism object integration (Y1) as a mediating variable. In addition, this study also assessed the relationship between tourist preference and tourism object integration based on the OLS (Ordinary Least Square) approach comprising the t-Statistics test (Partial Test), the f-Statistics test, and the stationarity test using Augmented DickeyFuller (ADF). As the first step of the analysis, the Level of Respondents Achievement (LRA) test was carried out. LRA analysis describes the characteristics of each research variable. The level of Respondents Achievement can be classified into the following groups: 
Table 1. Level of Respondents Achievement

\begin{tabular}{|c|c|c|}
\hline No & LRA & Criteria \\
\hline 1 & $00 \%-20 \%$ & Very weak \\
\hline 2 & $21 \%-40 \%$ & Weak \\
\hline 3 & $41 \%-60 \%$ & Strong Enough \\
\hline 4 & $61 \%-80 \%$ & Strong \\
\hline 5 & $81 \%-100 \%$ & Very Strong \\
\hline
\end{tabular}

Source: (Riduwan, 2006)

The line of thought in this study is illustrated in Figure 3 below:

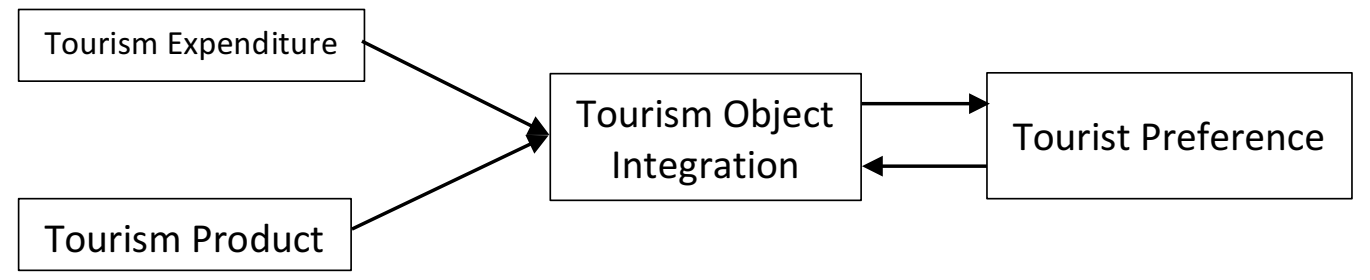

Figure 3. Conceptual Framework

Based on the above framework, an equation model can be formed as follows:

$$
\begin{aligned}
& \mathrm{Y}_{1}=\propto_{1} \mathrm{X}_{1}+\propto_{2} \mathrm{X}_{2}+\varepsilon_{1} \\
& \mathrm{Y}_{2}=\beta_{0} \widehat{\mathrm{Y}}_{1}+\varepsilon_{2} \\
& \widehat{\mathrm{Y}}_{1}=\gamma_{0} \mathrm{Y}_{2}+\varepsilon_{3}
\end{aligned}
$$

Where:

$\begin{array}{ll}\alpha, \beta, \gamma & : \text { Regression Coefficient } \\ \mathrm{Y}_{1} & : \text { Tourism Object Integration } \\ \hat{\mathrm{Y}} & : \text { Tourism Object Integration } \\ \mathrm{Y}_{2} & : \text { Tourism Preference } \\ \mathrm{X}_{1} & : \text { Tourism Expenditure } \\ \mathrm{X}_{2} & : \text { Tourism Product } \\ \varepsilon_{1} \varepsilon_{2} \varepsilon_{3} & : \text { Error Disturbance }\end{array}$

Equations (1) and (2) aim to see the relationship of tourism expenditure $\left(\mathrm{X}_{1}\right)$ and tourism product $\left(\mathrm{X}_{2}\right)$ toward tourist preference with tourism object integration $\left(\mathrm{Y}_{1}\right)$ as mediating variables. While equation (3) aims to prove the causal relationship between tourist preference $\left(\mathrm{Y}_{2}\right)$ and tourism object integration $\left(\mathrm{Y}_{1}\right)$.

\section{Definition of Variable Operations}

The variables used in this study are the result of a ratio data survey. Tourism expenditure (X1) describes the total costs incurred by tourists when traveling with transportation, accommodation, consumption, and recreation costs as indicators. Whereas, tourism product (X2) represents tourist 
perceptions of the various products at tourist sites with the indicators of food and drink facilities, recreational facilities, accommodation, transportation, tourist perception of the tourist attractions. Tourism object integration (Y1) represents the perceptions of tourists regarding the integration of the three attractions, whereas tourist preference (Y2) describes the satisfaction and interests of tourists before and after their visit.

\section{Stationary Test Results}

\section{Results and Analysis}

The results of the stationary test in Table 2 below show that all research variables are stationary at the level.

Table 2. Root Unit Test Results

\begin{tabular}{|l|c|c|c|c|}
\hline \multicolumn{1}{|c|}{ Variable } & $\begin{array}{c}\text { Unit Root } \\
\text { Test }\end{array}$ & $\begin{array}{c}\text { ADF Test } \\
\text { Statistic }\end{array}$ & $\begin{array}{c}\text { Critical } \\
\text { Values } \\
5 \%\end{array}$ & \multicolumn{1}{|c|}{ Note } \\
\hline Tourism Expenditure $\left(\mathrm{X}_{1}\right)$ & Level & -8.240731 & -2.899115 & Significant \\
\hline Tourism Product $\left(\mathrm{X}_{2}\right)$ & Level & -7.502435 & -2.899115 & Significant \\
\hline Tourism Object Integration $\left(\mathrm{Y}_{1}\right)$ & Level & -7.970888 & -2.899115 & Significant \\
\hline Tourist Preference $\left(\mathrm{Y}_{2}\right)$ & Level & -9.891934 & -2.899115 & Significant \\
\hline
\end{tabular}

Source: Author's Processed Results

\section{Description of Research Variables}

The descriptive data processing gave the Level of Respondents Achievements (LRA) values for each variable. The score for all variables shows the value of LRA which belongs in the fourth criterion, the strong criterion. The dependent variable of Tourist Preference has an LRA value of 66.20 percent. This value fits in the criterion of a strong LRA value which indicates that tourists tend to answer questions well. It can also be concluded that on average tourists have had a fairly good experience traveling to the city of Padang. Meanwhile, the LRA value for the tourism object integration variable is 73.83 percent. This value also fits in the fourth criterion. This means that the tourism attractions in Padang City are well integrated. The variables of tourism expenditure and tourism product have LRA values of 61.12 and 65.31 percent, respectively. Thus, both variables belong in the strong criterion, which means that the perception of tourists about the cost of tourism and the quality of tourism products in the city of Padang tends to be good.

\section{Analysis Results}

The following Table 3 presents the results of the analysis of the influence of tourism expenditure $\left(\mathrm{X}_{1}\right)$ and tourism product $\left(\mathrm{X}_{2}\right)$ on tourism object integration $\left(\mathrm{Y}_{1}\right)$.

Table 3. Model Estimation Results (1)

\begin{tabular}{crrrr}
\hline Variable & Coefficient & Std. Error & t-Statistic & Prob. \\
\hline \hline $\mathrm{X}_{1}$ & 0.531388 & 0.092245 & 5.760579 & 0.0000 \\
$\mathrm{X}_{2}$ & 0.626406 & 0.085226 & 7.349976 & 0.0000 \\
\hline
\end{tabular}

Table 2 shows that tourism expenditure $\left(\mathrm{X}_{1}\right)$ and tourism product $\left(\mathrm{X}_{2}\right)$ have a significant influence on Tourism Object Integration. Thus, the equation model can be formulated as follows:

$$
\mathrm{Y}_{1}=0.5314 \mathrm{X}_{1}+0.6264 \mathrm{X}_{2}+\varepsilon
$$


Based on the above equation we find that the coefficient of determination $X_{1}$ is 0.5314 , meaning that lower expenditure means increased tourism object integration. These results are in line with another study in Taiwan (Tsai, Hsu, Chen, Lin, \& Chen, 2010) which concluded that an integrated approach to tourism can reduce tourism expenditure, and tourism expenditure can also be a factor that influences the integration of tourism object. Cost is a key tourism variable and is often the main focus of research on tourism. In fact, tourism destinations will be abandoned if tourism expenditure is too high but tourists are not satisfied.

The analysis of variable $\mathrm{X}_{2}$ based on the equation shows that a higher value for tourism product leads to higher tourism object integration. Tourism products are the main aspects of a person's consideration in selecting tourist destinations, as found by (Elliot \& Papadopoulos, 2015). Their study highlighted that tourists' confidence in tourism products plays an important role in building trust in tourism objects as a whole. Thus, creating a positive image of tourism products can be a major focus in the development of integrated tourism. Both analyses show that tourism expenditure and tourism product are key variables in supporting the integration of tourist attractions. As such, the continued differentiation and innovation of tourism products will benefit the various tourism-related sectors.

Next is the result of the analysis of the influence of the variable $\hat{Y} 1$ (fitted) on Tourist Preference $\left(\mathrm{Y}_{2}\right)$ as shown in Table 4 below, the $\hat{\mathrm{Y}}_{1}$ variable is the $\mathrm{Y}$ variable that has been influenced by variables $\mathrm{X}_{1}$ and $\mathrm{X}_{2}$.

Table 4. Model Estimation Results (2)

\begin{tabular}{ccccc}
\hline Variable & Coefficient & Std. Error & t-Statistic & Prob. \\
\hline \hline$\hat{Y}_{1}$ & 0.889090 & 0.029766 & 29.86938 & 0.0000 \\
\hline
\end{tabular}

Table 4 shows a significant influence of tourism object integration $\left(\mathrm{Y}_{1}\right)$ on tourist preference $\left(\mathrm{Y}_{2}\right)$. The equation that was based on the results of the analysis below, shows that tourism object integration influences tourist preference as high as 88.91 percent. This shows that the integration of tourism objects offers higher satisfaction for tourists.

$$
\mathrm{Y}_{2}=0.8891 \widehat{\mathrm{Y}}_{1}+\varepsilon
$$

Tourism object integration and tourist preference are very closely related to tourism expenditure and tourism product because tourism object integration is formed by these two variables. This relationship is also explained by c, i.e., the main determinant of tourist preference is visitor satisfaction in relation to tourism costs.

Next is the result of the analysis of the influence of the Tourist Preference $\left(\mathrm{Y}_{2}\right)$ on Tourism Object Integration $\left(\mathrm{Y}_{1}\right)$, where the fitted $\mathrm{Y}_{1}$ variable used.

Table 5. Model Estimation Results (3)

\begin{tabular}{crrrr}
\hline Variable & Coefficient & Std. Error & t-Statistic & Prob. \\
\hline \hline $\mathrm{Y}_{2}$ & 1.034319 & 0.034628 & 29.86938 & 0.0000 \\
\hline
\end{tabular}

Table 5 above shows that tourist preference has a significant influence on tourism object integration which as is evident from their probability values. Thus, the equation can be formed as follows:

$$
\widehat{\mathrm{Y}}_{1}=1.034 \mathrm{Y}_{2}+\varepsilon
$$

The significance between these variables indicates a causal relationship between tourism object integration $\left(\mathrm{Y}_{1}\right)$ and tourist preference. This means that in addition to tourism object integration affecting tourist preference, tourist preference can also affect tourism integration. 
Tourism object integration can reduce tourism expenditure and increase the variety of tourism products so that tourists have more complex choices for tourism products. These advantages attract tourists to visit tourist attractions. Conversely, when visitors feel satisfied with a tourist attraction, they will visit it again and explore new related attractions, thereby increasing the integration between these attractions.

\section{Discussion and Implication}

This study found a causal relationship between the integration of tourist objects with tourist preferences, this result is in line with research conducted by (Kuralbayev et al., 2017), namely tourist preferences that can also be determined by the diversity of products in tourist attractions have a relationship that affects each other with integration tourist attraction. This finding shows that it is very important for stakeholders, especially institutions in the tourism sector, to support the creation of good integration between attractions to increase tourist preferences for attractions in the Integrated Tourism Region of Padang City.

Efforts to improve the integration of these attractions can be done by increasing the connecting infrastructure between attractions, especially transportation infrastructure, recreational facilities that are mutually integrated, and no less important is the use of communication media. As one form of media utilization, the city government of Padang can do so through an application specifically designed to promote the Integrated Tourism Region of Padang City.

The use of applications, especially those currently popular and widely used in various countries, is an augmented reality-based application that is believed to maximize promotion in the tourism sector. The use of augmented reality is superior to classical promotional media because it can produce information that is more interactive, and integrated as a virtuality and multimedia component, besides that the community at this time is almost inseparable from the use of mobile phones thereby increasing the chances of success of this application (Lerena, Andina, \& Grijalva, 2018; Phithak \& Kamollimsakul, 2020; Safitri, Yusra, Hermawan, Ripmiatin, \& Pradani, 2017). Thus, the promotion of just one tourist attraction will have an impact on other attractions in the Integrated Tourism Region of Padang City. That is, the success of promotion in one tourist attraction will be a stimulus for other attractions.

\section{Research Limitation and Future Direction}

This research relies heavily on the demand-side approach, namely from the consumer or tourist attraction. Research (Zemla, 2016) considers that the demand side approach has weaknesses due to the high subjectivity due to differences in the characteristics of tourists themselves, for example, differences in economic conditions, socio-cultural backgrounds, religions, and so on. Therefore for further researchers to make approaches that can be more effective, for example collaborating between the demand side approach and the supply-side approach, namely service providers in the tourism sector.

\section{Conclusions}

This study indicates that various tourism variables are interrelated. The causal relationship between tourism object integration and tourist preference explains that the existence of integrated tourism will increase opportunities for tourists to visit the Integrated Tourism Area in Padang City, whereas tourist satisfaction that encourages tourists to visit again will increase the tourism object integration in the city. Lower tourism expenditure because of the increased integration of tourism objects leads to more diverse choices for tourists. Therefore, improvements need to be made to increase the integration of tourism objects to provide economic benefits for the City of Padang. This will especially benefit the communities around tourism objects who are the main actors in the tourism sector.

The use of information technology is key in developing tourism objects because it can be used as an effective promotional media, especially social media. However, the Padang City Government must first increase investment in the tourism sector to support tourism activities, especially transportation, recreational facilities, and infrastructure. 


\section{Acknowledgement}

The authors wish to thank the Rector of Universitas Negeri Padang for supporting this research in the form of Non-Tax State Revenue (Penerimaan Negara Bukan Pajak (PNBP) funding, the Research and Community Service Institute (LP2M), and the research team for its cooperation.

\section{References}

Andereck, K. L., Valentine, K. M., Knopf, R. C., \& Vogt, C. A. (2005). Residents' Perceptions of Community Tourism Impact. Annals of Tourism Research, 32(4), 1056-1076. https://doi.org/10.1016/j.annals.2005.03.001

Cawley, M., \& Gillmor, D. A. (2008). Integrated Rural Tourism : Concepts and Practice. Annals of Tourism Research, 35(2), 316-337. https://doi.org/10.1016/j.annals.2007.07.011

DPMPTSP. (2017). Pengembangan Kawasan Wisata Pantai Padang. Kota Padang: DPMPTSP Kota Padang.

Elliot, S., \& Papadopoulos, N. (2015). Of Products and Tourism Destinations : An Integrative , CrossNational Study of Place Image. Journal of Business Research. https://doi.org/10.1016/j.jbusres.2015.08.031

Hearne, R. R., \& A, Z. M. S. (2016). The Use of Choice Experiment in the Analysis of Tourist Preference for Ecotourism Development in Costa Rica. Journal of Environmental Management, 65(2), 153-163. https://doi.org/10.1006/jema.2001.0541

Kuralbayev, A., Sevim, B., \& Abishev, N. (2017). Econometrical Analysis of the Demand for Entrance Tourism in. International Journal of Economics and Financial Issues, 7(1), 262-268.

Lee, C., \& Chang, C. (2008). Tourism development and economic growth : A closer look at panels, 29, 180-192. https://doi.org/10.1016/j.tourman.2007.02.013

Lerena, J., Andina, M., \& Grijalva, J. (2018). Mobile application to promote the Malecón 2000 tourism using augmented reality and geolocation. Proceedings - 3rd International Conference on Information Systems and Computer Science, INCISCOS 2018, 2018-Decem, 213-220. https://doi.org/10.1109/INCISCOS.2018.00038

Lorde, T., Li, G., \& Airey, D. (2015). Modeling Caribbean Tourism Demand: An Augmented Gravity Approach. https://doi.org/10.1177/0047287515592852

Oliver, T., \& Jenkins, T. (2003). Sustaining Rural Landscapes: The role of Integrated Tourism. Landscape Research, 28(3), 293-307. https://doi.org/10.1080/01426390306516

Pham, K., \& Vogt, C. (2019). Local Residents ' Perceptions about Tourism Development. In 2019 ttra International Conference.

Phithak, T., \& Kamollimsakul, S. (2020). Korat Historical Explorer: The Augmented Reality Mobile Application to Promote Historical Tourism in Korat. Proceedings of the 2020 the 3rd International Conference on Computers in Management and Business, 283-289.

Riduwan. (2006). Rumus dan Data dalam Aplikasi Statistika. (Aqib, Zainal, \& A. Murtadlo, Eds.). Bandung: Alfabeta.

Safitri, R., Yusra, D. S., Hermawan, D., Ripmiatin, E., \& Pradani, W. (2017). Mobile tourism application using augmented reality. 2017 5th International Conference on Cyber and IT Service Management, CITSM 2017, (August). https://doi.org/10.1109/CITSM.2017.8089305

Schiefelbusch, M., Jain, A., Schafer, T., \& Muller, D. (2007). Transport and tourism : Roadmap to Integrated Planning Developing and Assessing Integrated Travel Chains. Journal of Transport G, 15(September 2000), 94-103. https://doi.org/10.1016/j.jtrangeo.2006.12.009

Sevim, B. (2017). Econometrical Analysis of the Demand for Entrance Tourism in Kazakhstan, (January).

Shafieea, S., Ghatari, Ali Rajabzadeh Hasanzadeha, A., \& Jahanyan, S. (2019). Developing a model for sustainable smart tourism destinations: A systematic review. Tourism Management Perspectives, 31, 287-300. https://doi.org/https://doi.org/10.1016/j.tmp.2019.06.002

Shalini, N., \& Masood, H. (2010). An Empirical Study of Tourist Preferences Using Conjoint Analysis. International Journal of Business Science \& Applied Management, 5(2), 1-16. 
Retrieved from http://hdl.handle.net/10419/190613

Toth, G., \& David, L. (2010). Tourism and Accessibility: An Integrated Approach. Apllied Geography, 3(4), 666-677. https://doi.org/10.1016/j.apgeog.2010.01.008

Tsai, W.-H., Hsu, J.-L., Chen, C.-H., Lin, W.-R., \& Chen, S.-P. (2010). International Journal of Hospitality Management An Integrated Approach for Selecting Corporate Social Responsibility Programs and Costs Evaluation in the International Tourist Hotel. International Journal of Hospitality Management, 29(3), 385-396. https://doi.org/10.1016/j.ijhm.2009.12.001

UNWTO. (2008). Tourism Highlight.

UNWTO. (2019). 2018 : International tourist arrivals worldwide reach 1.4 billion two years ahead of forecasts, $17(1), 1-5$.

WTTC. (2019). Travel \& Tourism Economic Impact 2019 World.

Yilmaz, E. S., \& Aytekin, M. (2018). Determinants of Tourist Preferences of the Mediterranean Region in Turkey. Administrative Science, 8(4), 1-14. https://doi.org/10.3390/admsci8040081

Zemla, M. (2016). Tourism Destination: The Networking Approach. Movarian Geographical Report, 24(4), 2-14. https://doi.org/10.1515/mgr-2016-0018 